\title{
HEAVY METALS PARTITION BETWEEN LEACHATE AND SOLIDS IN THE COURSE OF MUNICIPAL SEWAGE TREATMENT
}

\author{
Hanna Obarska-Pempkowiak* \\ Wieslaw Butajlo** \\ Janusz Pempkowiak*** \\ * Gdansk University of Technology, Poland \\ ** Regional Found of Environment Protection and Water Management, \\ Poland \\ *** Koszalin Technical University, Poland
}

\begin{abstract}
Measurements of heavy metals contents $(\mathrm{Cu}, \mathrm{Zn}, \mathrm{Pb}, \mathrm{Cd})$ were carried out in liquid and solid fractions of sewage and sewage sludge after stabilization as well as dewatering.

Investigation was carried out in municipal WWTP „Wschod” in Gdansk. The flow of sewage was equal to $88000 \mathrm{~m}^{3} / \mathrm{d}$. The treatment consists of two stages: the first stage mechanical (4screens, 2 sandtraps, 4 primary sedimentation tanks) and the second stage advanced biological MUCT system (6 reactors - each incorporating the following chambers: dephosphatation, pre-denitrification, denitrification and nitrification followed by 2 secondary sedimentation tanks) modified by introduction of an additional chamber which secures dioxidation of sewage recirculated between nitrification and denitrification chambers. Sewage sludge (primary and secondary) is stabilized by fermentation. The last step of sludge utilization is mechanical dewatering.
\end{abstract}

Samples of sewage were collected at the following points of the WWTP: at the beginning - raw sewage, mechanically treated sewage and biologically treated sewage. Samples of reject waters after thickening and after mechanical dewatering of sludge were collected too.

The following types of sewage sludge were investigated: primary, secondary, thickened (on the Klein press), digested and mechanically dewatered (Noxon centrifuges).

In the sampling points samples were collected twice per month during the 6 months period in the years 2000-2001.

Inflowing sewage carried the following loads of heavy metals: $\mathrm{Zn}-27.2 \mathrm{~kg} / \mathrm{d}, \mathrm{Cu}-5.4$ $\mathrm{kg} / \mathrm{d}, \mathrm{Pb}-1.3 \mathrm{~kg} / \mathrm{d}$ and $\mathrm{Cd}-0.4 \mathrm{~kg} / \mathrm{d}$. 
KALMAR ECO-TECH'03

Bioremediation and Leachate Treatment

KALMAR, SWEDEN, November 25-27, 2003

Basing on balances of heavy metals loads it was proved that $87.0 \% \mathrm{Zn}$ and $83.0 \% \mathrm{Cu}$ were kept in sludge.

Among analysed sewage sludge samples, the highest contents of heavy metals was found in sludge after mechanical dewatering and in the mixture of primary and secondary sludge $(\mathrm{Zn}-780.4 \mathrm{mg} / \mathrm{kg}$ d.m., $\mathrm{Cu}-144.6 \mathrm{mg} / \mathrm{kg}$ d.m., $\mathrm{Pb}-5.4 \mathrm{mg} / \mathrm{kg} \mathrm{d} . \mathrm{m}$. and $\mathrm{Cd}-$ $2.4 \mathrm{mg} / \mathrm{kg} \mathrm{d} \mathrm{m}$. The contents of heavy metals in examined sludge were compared with Polish admissible loads of metals applied with sludge to soil fertilization. Basing on the findings, admissible loads of sewage sludge to agricultural land were not exceeded.

\section{KEYWORDS}

heavy metals, soil, leachate, sewage sludge, municipal sewage treatment, MUCT technology

\section{INTRODUCTION}

Analysis of sewage sludge composition from municipal wastewater treatment plants (WWTPs) usually is effective for land application. Both nutrients and specific indicators are most often considered. The former group consists of nutrient elements $(\mathrm{N}, \mathrm{P}, \mathrm{K})$ and organic substances, while the term specific indicators refers to those heavy metals, that reach higher concentrations in sewage sludge than in unpolluted soil $[4,6]$. On this basis the following elements capable of causing soil pollution have been identified: arsenic, boron, cadmium, copper, mercury, lead, zinc, chromium and nickel.

Sewage sludge can have different composition, depending on sewage quality and both the applied sewage treatment method and the methods of sludge thickening, dewatering and stabilization. Sludge composition is also affected by processing methods - for instance sludge stored in lagoons, sludge from primary sedimentation tanks or sludge obtained in chemical precipitation process. Obviously, the dry matter content in sludge depends on effectiveness of dewatering processes, however the fluctuations of soluble substances content during sludge processing are not known. Filtration and centrifugation affect distribution of both nutrients and trace metals. For instance, Sommers [3] proved that part of sludge contains less than $0.5 \%$ of total amount of potassium and sodium, while cadmium, magnesium, iron and aluminium are usually attached to sludge flocs. Sulphates and chlorides of these metals are sometimes used for improving sedimentation characteristics of sludge and dewatering process effectiveness. The effect of this practice on heavy metals distribution is not known.

Metals can exhibit inhibiting or toxic effect on activated sludge microorganisms. Although activated sludge can get adapted, but lack of certain species of microorganisms can worsen effectiveness of sewage treatment. For instance $\mathrm{pH}$ decrease (taking place during fermentation of sewage sludge) results in releasing of heavy metals ions from sludge [3]. Also increase of temperature (for instance during mesophillous fermentation) can strengthen toxic impact of heavy metals on microorganisms. 
KALMAR ECO-TECH'03

Bioremediation and Leachate Treatment

KALMAR, SWEDEN, November 25-27, 2003

The aim of the study is evaluation of selected heavy metals $(\mathrm{Cu}, \mathrm{Pb}, \mathrm{Cd}$ and $\mathrm{Zn})$ partition between sewage, sludge and reject water in the course of sludge processing in WWTP in Gdansk, after introduction of highly-effective MUCT treatment technology.

\section{DESCRIPTION OF EWAGE TREATMENT TECHNOLOGICAL LINE IN WWTP IN GDANSK}

The sewage $\left(88000 \mathrm{~m}^{3} / \mathrm{d}\right)$ from Gdansk and adjacent area is discharged to WWTP by separate sewarage system via two pumping stations of the 63000 and $25000 \mathrm{~m}^{3} / \mathrm{d}$ capacities.

Mechanical treatment consists of screens, aerated sand trap and radial primary sedimentation tanks. Then sewage via gravitational channel outflow to transitional pumping station. In distribution chamber of the pumping station the sewage is divided into 6 equal streams. Each of the streams is directed to one of 6 biological reactors of modified UCT system, co-operating with 12 radial secondary sedimentation tanks. Each of reactors consists of 5 separate chambers. In the first three chambers the following processes take place subsequently: dephosphatation, denitrification and nitrification. Dephosphatation is periodically supported with PIX coagulant. Classic MUCT process units were additionally equipped with an intermediate chamber located in the denitrification chamber, where either nitrification or denitrification can take place and with the final fifth chamber, where deoxidation of recirculate from the nitrification chamber to the denitrification chamber is performed (Fig. 1). The reject waters generated during mechanical thickening and dewatering of sewage sludge are directed to the

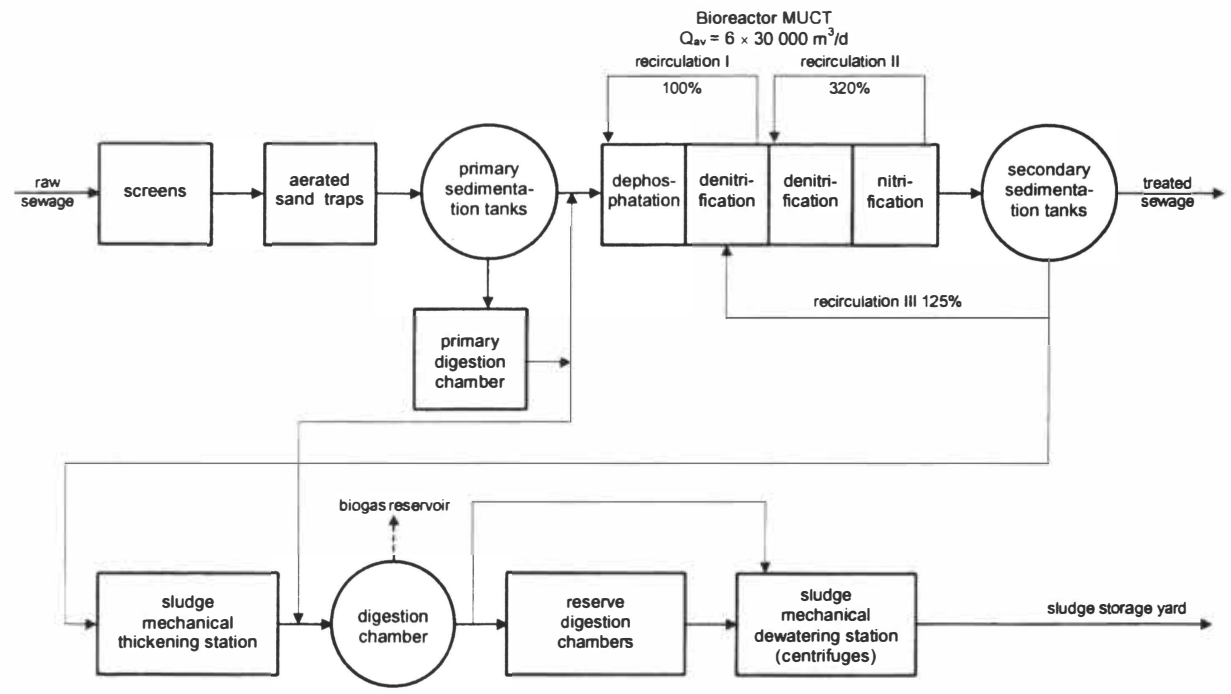

technological line of sewage treament (after the screens).

Fig. 1. Technological scheme of WWTP Gdansk- ,Wschod" 


\section{SEWAGE SLUDGE PROCESSING IN THE WWTP}

During the sewage treatment process two types of sludge are generated: primary sludge from primary sedimentation tanks (average d.m. concentration - 3.5\%) and excess secondary sludge from secondary sedimentation tanks (average d.m. concentration - 5.8\% after mechanical thickening). A separate fermenter, designed as three-chamber reactor with full mixing, is associated with primary sedimentation tanks. About a half of primary sludge is directed to the fermenter in order to produce volatile fatty acids (VFA's). VFA's are generated in the fermenter are discharged before primary sedimentation tanks. This solution guaranties that sewage inflowing to biological dephosphatation chambers are enriched in small-size organic compounds, necessary for the process.

Primary and secondary sludges are mixed in a separate chamber of $50 \mathrm{me}^{3}$ volume, thickened, and pumped into two digestion chambers, of the volume of $7000 \mathrm{me}^{3}$ each.

\section{MATERIALS AND METHODS}

The objective of investigations was evaluation of the amount of selected heavy metals $(\mathrm{Cu}, \mathrm{Pb}, \mathrm{Cd}$ and $\mathrm{Zn})$ in flowing sewage (5 sampling points) and sludge (another 5 sampling points). Location of sampling points is presented in the Fig. 2.

The samples of sewage were collected at the following points of technological line: at the inflow, after mechanical treatment (after primary sedimentation tanks), after biological treatment (after bio-reactors), reject waters after mechanical thickening of excess activated sludge (after Klein presses) and reject waters after mechanical dewatering of digested sludge (after Noxon centrifuges).

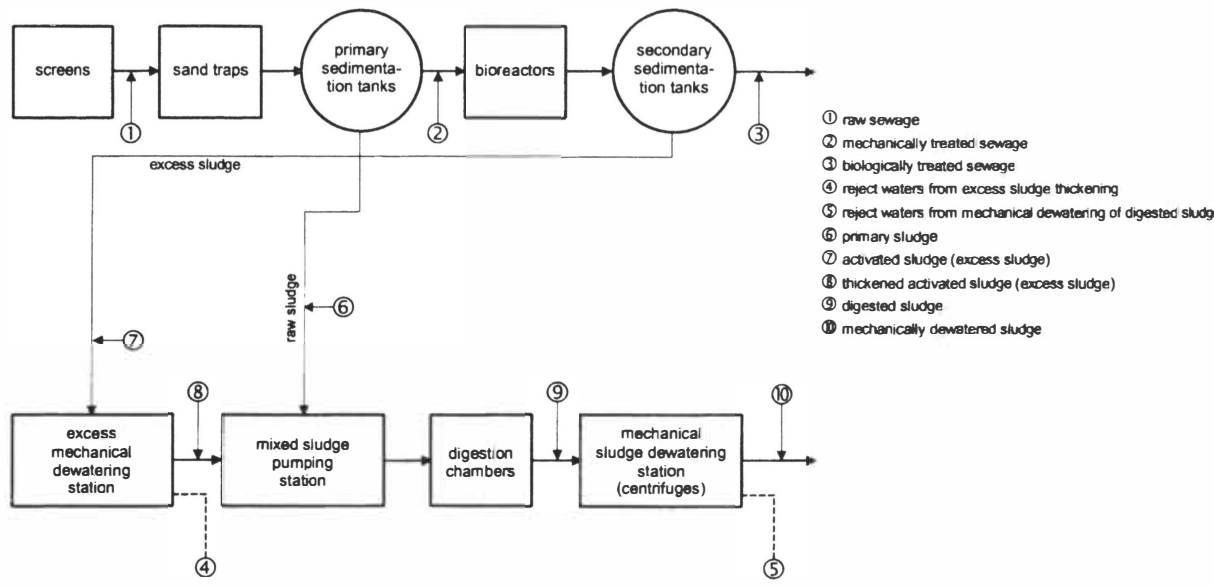

Fig. 2. Location of sewage, reject waters and sludge sampling points

The following samples of sludge were collected: primary sludge, excess activated sludge (collected at operation chamber of excess sludge), thickened excess activated sludge 
KALMAR ECO-TECH'03

Bioremediation and Leachate Treatment

KALMAR, SWEDEN, November 25-27, 2003

(after Klein presses), sludge discharged from digestion chambers and centrifugated sludge (transported to the local storage yard at the WWTP area).

The averaged samples of sewage, reject waters and sludge were collected two times a month in 6 months period in the years 2000-2001.

In the sewage samples the determinations of suspended solids concentration were made; in sludge samples the d.m. content was determined, both according to guidelines given by Hermanowicz et al. [2].

Determinations of heavy metals concentrations in sewage were conducted both in the solution and in the separated suspension. The volume of $1000 \mathrm{dm}^{3}$ of sewage was filtered on membrane filters of the pore diameter $0.45 \mu \mathrm{m}$. The obtained solution was evaporated to dryness and then dissolved in $0.1 \mathrm{~mol} / \mathrm{dm}^{3}$ solution of $\mathrm{HNO}_{3}$. The filters were dried and digested in the mixture of acids $\mathrm{HCl}: \mathrm{HNO}_{3}(3: 1)$. The acids were evaporated and the residue was dissolved in $0.1 \mathrm{~mol} / \mathrm{dm}^{3}$ solution of $\mathrm{HNO}_{3}$.

The procedure of heavy metals determination in sewage sludge was as follows. A $1.000 \mathrm{~g}$ sample of uniform sludge was dissolved in $5 \mathrm{~cm}^{3}$ of $\mathrm{HCl}: \mathrm{HNO}_{3}(3: 1)$ mixture in the period of 2 hours at the temperature of $80^{\circ} \mathrm{C}$. The final mixture was centrifugated, evaporated to dryness and the residue was dissolved in $0.1 \mathrm{~mol} / \mathrm{dm}^{3}$ solution of $\mathrm{HNO}_{3}$. Then the content of heavy metals was measured.

The measurements of heavy metals concentrations were carried out in a Video 11E atomic absorption spectrometer (Therom Jarrel Ash, USA).

\section{RESULTS}

Wastewater directed to the WWTP is a mixture of domestic and industrial sewage. The share of industrial sewage in the total sewage inflow is $10 \%$. The daily inflow of sewage and daily amount of generated sludge is given in Table 1 . The reject waters from sludge thickening and dewatering are recirculated to the technological line of sewage treatment (Fig. 2). Thus the amount of treated sewage is a sum of sewage inflow and reject waters. The volume of reject waters from thickening belt presses is approximately $2100 \mathrm{~m}^{3} / \mathrm{d}$ and in the dewatering process another $500 \mathrm{~m}^{3} / \mathrm{d}$ is generated.

The average values of pollution indicators in sewage discharged to the WWTP in the years 2000-2001 with standard deviations and variation coefficient (in percents) is given in Table 2.

The values of variation coefficients (relative measure of dispersion) change from 7.3 to $31.7 \%$. The highest values were noted for Kjeldahl nitrogen and the lowest - for $\mathrm{N}_{-} \mathrm{NH}_{4}{ }^{+}$. The results indicate that sewage quality (in the range of analysed parameters) is stable.

The results of heavy metals content $(\mathrm{Zn}, \mathrm{Cu}, \mathrm{Pb}$ and $\mathrm{Cd})$ in total suspended solids, determined in sewage and reject waters are presented in Table 3 . The reject waters from sludge dewatering process had the highest concentration of TSS $\left(2800 \mathrm{mg} / \mathrm{dm}^{3}\right)$, while the lowest TSS concentration was observed in biologically treated sewage $\left(14 \mathrm{mg} / \mathrm{dm}^{3}\right)$. 
KALMAR ECO-TECH'03

Bioremediation and Leachate Treatment

KALMAR, SWEDEN, November 25-27, 2003

The heavy metals content in TSS was variable - for instance for Cd it changed from 1.9 $\mu \mathrm{g} / \mathrm{g} \mathrm{d} . \mathrm{m}$. in raw sewage to $12.5 \mu \mathrm{g} / \mathrm{g} \mathrm{d}$.m. in biologically treated sewage, and for $\mathrm{Zn}$ it varied from $491.4 \mu \mathrm{g} / \mathrm{g} \mathrm{d} . \mathrm{m}$. in reject waters from belt presses to $894.2 \mu \mathrm{g} / \mathrm{g} \mathrm{d}$.m. in mechanically treated sewage.

Table 1. The average daily sewage inflow to the WWTP, the amount of generated sludge and reject waters from sludge thickening and dewatering in the years $2000-2001, \mathrm{~m}^{3} / \mathrm{d}$

\begin{tabular}{|l|c|c|c|}
\hline \multicolumn{1}{|c|}{ Type of sewage* or sludge } & $\begin{array}{c}\text { Average daily } \\
\text { quantity of } \\
\text { sewage/sludge }\end{array}$ & $\begin{array}{c}\text { Standard } \\
\text { deviation }\end{array}$ & $\begin{array}{c}\text { Relative standar } \\
\text { deviation, \% }\end{array}$ \\
\hline Raw sewage & 88000 & 4.8 & 5.4 \\
\hline Reject waters from presses & 2100 & 190.7 & 9.3 \\
\hline Reject waters from centrifuges & 500 & 196.1 & 34.6 \\
\hline Primary sludge & 500 & 95.2 & 19.0 \\
\hline Excess sludge & 2500 & 1203.4 & 48.2 \\
\hline Thickened excess sludge & 270 & 101.4 & 37.2 \\
\hline Digested sludge & 770 & 139.5 & 16.2 \\
\hline Dewatered sludge & 140 & 31.7 & 22.5 \\
\hline
\end{tabular}

* The volume of sewage after mechanical and biological treatment corresponds to the volume of raw sewage and reject waters from presses and centrifuges

Table 2. The average values of pollution indicators in sewage discharged to the WWTP in the years 2000-2001 with standard deviations and variation coefficient

\begin{tabular}{|l|c|c|c|c|}
\hline Parameter & Unit & $\begin{array}{c}\text { Average } \\
\text { value }\end{array}$ & $\begin{array}{c}\text { Standard } \\
\text { deviation }\end{array}$ & $\begin{array}{c}\text { Relative standard deviation, } \\
\%\end{array}$ \\
\hline $\mathrm{BOD}_{5}$ & $\mathrm{mgO}_{2} / \mathrm{dm}^{3}$ & 390.0 & 46.5 & 12.0 \\
\hline $\mathrm{COD}_{\mathrm{Cr}}$ & $\mathrm{mgO} / \mathrm{dm}^{3}$ & 900.0 & 83.6 & 9.4 \\
\hline $\mathrm{Kjeldahl} \mathrm{N}$ & $\mathrm{mgN} / \mathrm{dm}^{3}$ & 70.0 & 3.8 & 4.5 \\
\hline $\mathrm{N} \mathrm{NH}_{4}{ }^{+}$ & $\mathrm{mgN} / \mathrm{dm}^{3}$ & 42.7 & 3.1 & 7.3 \\
\hline $\mathrm{P}_{\text {tot }}$ & $\mathrm{mgP} / \mathrm{dm}^{3}$ & 12.6 & 1.0 & 8.1 \\
\hline $\mathrm{TSS}$ & $\mathrm{mg} / \mathrm{dm}^{3}$ & 460.0 & 64.6 & 14.0 \\
\hline
\end{tabular}

The results of measurements of heavy metals concentration in sewage, TSS and reject waters provided the basis for evaluation of daily balance of the loads of analysed metals flowing through the WWTP technological line. The load of metals was calculated as the multiplication product of heavy metal concentration and the volume of sewage or reject waters in the analysed sampling point (Table 4, Fig. 3). 
KALMAR ECO-TECH'03

Bioremediation and Leachate Treatment

KALMAR, SWEDEN, November 25-27, 2003

Table 3. The concentrations of TSS and heavy metals in solution and suspension

\begin{tabular}{|c|c|c|c|c|c|}
\hline \multirow[b]{2}{*}{ Type of sewage } & \multirow[b]{2}{*}{ TSS mg/dm ${ }^{3}$} & $\mathrm{Zn}$ & $\mathrm{Cu}$ & $\mathrm{Pb}$ & $\mathrm{Cd}$ \\
\hline & & \multicolumn{4}{|c|}{$\begin{array}{c}\text { solution, } \mu \mathrm{g} / \mathrm{dm}^{3} \\
\text { suspension, } \mu \mathrm{g} / \mathrm{g} \text { d.m. }\end{array}$} \\
\hline Raw sewage & 460 & $\begin{array}{c}314.9 \\
662\end{array}$ & $\begin{array}{c}\mathbf{6 1 . 2} \\
158.2\end{array}$ & $\begin{array}{l}<\mathbf{1 5 . 0} \\
20.2\end{array}$ & $\begin{array}{c}<5.0 \\
1.9\end{array}$ \\
\hline $\begin{array}{l}\text { Mechanically treated } \\
\text { sewage }\end{array}$ & 312 & $\begin{array}{c}206.0 \\
894\end{array}$ & $\begin{array}{c}34.7 \\
148.9\end{array}$ & $\begin{array}{l}<\mathbf{1 5 . 0} \\
11.5\end{array}$ & $\begin{array}{c}<5.0 \\
2.7\end{array}$ \\
\hline $\begin{array}{l}\text { Biologically treated } \\
\text { sewage }\end{array}$ & 14 & $\begin{array}{l}40.4 \\
621\end{array}$ & $\begin{array}{c}6.8 \\
98.3\end{array}$ & $\begin{array}{l}<\mathbf{1 5 . 0} \\
11.2\end{array}$ & $\begin{array}{l}<\mathbf{5 . 0} \\
12.5\end{array}$ \\
\hline $\begin{array}{l}\text { Reject waters from } \\
\text { presses }\end{array}$ & 450 & $\begin{array}{c}677.7 \\
491\end{array}$ & $\begin{array}{l}\mathbf{2 5 9 . 0} \\
127.3\end{array}$ & $\begin{array}{c}\mathbf{1 6 . 0} \\
3.5\end{array}$ & $\begin{array}{c}<5.0 \\
2.3\end{array}$ \\
\hline $\begin{array}{l}\text { Reject waters from } \\
\text { centrifuges }\end{array}$ & 2800 & $\begin{array}{c}\mathbf{6 5 7 2 . 0} \\
651\end{array}$ & $\begin{array}{l}\mathbf{1 1 1 0} \\
123.6\end{array}$ & $\begin{array}{c}\mathbf{3 8 . 0} \\
3.0\end{array}$ & $\begin{array}{c}\mathbf{2 0 . 6} \\
2.3\end{array}$ \\
\hline
\end{tabular}

Table 4. The average daily load of analysed heavy metals in sewage and reject waters from sludge thickening and dewatering in the WWTP "Wschod"

\begin{tabular}{|l|c|c|c|c|}
\hline \multirow{2}{*}{\multicolumn{1}{|c|}{ Type of sewage }} & $\mathrm{Zn}$ & $\mathrm{Cu}$ & $\mathrm{Pb}$ & $\mathrm{Cd}$ \\
\cline { 2 - 5 } & \multicolumn{4}{|c|}{$\mathrm{kg} / \mathrm{d}$} \\
\hline Raw sewage & 27.7 & 5.4 & 1.3 & 0.4 \\
\hline Mechanically reated sewage & 18.1 & 3.0 & 1.8 & 0.4 \\
\hline Biologically treated sewage & 3.5 & 0.6 & 1.3 & 0.4 \\
\hline Reject waters from presses & 1.4 & 0.5 & 0.04 & $<0.001$ \\
\hline Reject waters from centrifuges & 3.3 & 0.5 & 0.1 & 0.01 \\
\hline
\end{tabular}


KALMAR ECO-TECH'03

Bioremediation and Leachate Treatment

KALMAR, SWEDEN, November 25-27, 2003

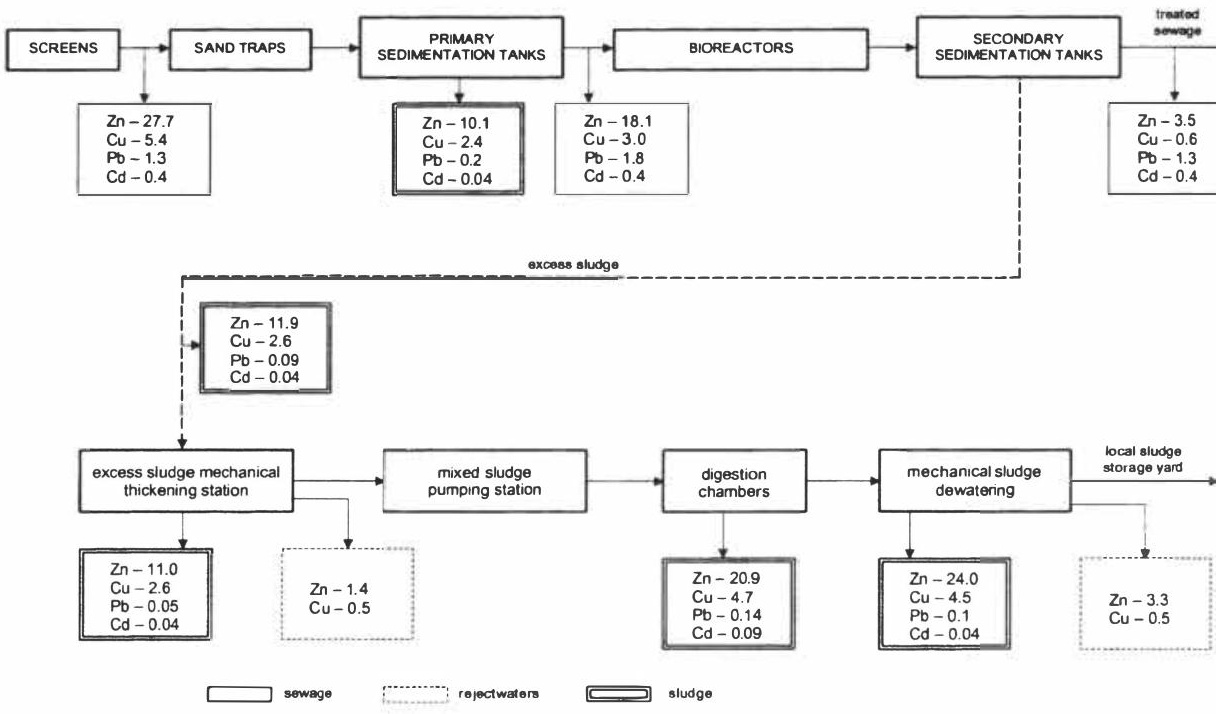

Fig. 3. Daily average flow of heavy metals $(\mathrm{Zn}, \mathrm{Cu}, \mathrm{Pb}, \mathrm{Cd})$ in sewage, reject waters and sewage sludge, $\mathrm{kg} / \mathrm{d}$

The loads of heavy metals in the inflowing sewage were as follows: $\mathrm{Zn}-27.7 \mathrm{~kg} / \mathrm{d}, \mathrm{Cu}-$ $5.4 \mathrm{~kg} / \mathrm{d}, \mathrm{Pb}-1.3 \mathrm{~kg} / \mathrm{d}$ and $\mathrm{Cd}-0.4 \mathrm{~kg} / \mathrm{d}$. Very small loads of $\mathrm{Zn}$ and $\mathrm{Cu}(3.5$ and 0.6 $\mathrm{kg} / \mathrm{d}$, respectively) in sewage outflowing from the plant suggest that huge quantity of these elements is retained in sludge (on average $87.0 \% \mathrm{Zn}$ and $83.0 \% \mathrm{Cu}$ ). On the other hand, $\mathrm{Pb}$ and $\mathrm{Cd}$ were discharged to the Bay of Gdansk with treated sewage. The concentrations of these elements in the effluent $\left(\mathrm{Pb}<15 \mu \mathrm{g} / \mathrm{dm}^{3}, \mathrm{Cd}<5 \mu \mathrm{g} / \mathrm{dm}^{3}\right)$ are lower than the admissible concentrations defined in Polish regulations [5].

Comparing the loads of heavy metals in reject waters generated during mechanical dewatering of digested sludge and the loads discharged with the reject waters, proved that huge amounts of heavy metals were released from the sludge. On the contrary, mechanical thickening of excess sludge did not lead to such effiects.

The daily quantities of heavy metals in the generated sludge were calculated as a multiplication product of the daily sludge production and the average content of the analysed heavy metals. The contents of d.m. in sludge generated during various stages of processing were also used in the calculations. Obtained results are presented Table 5. 
KALMAR ECO-TECH'03

Bioremediation and Leachate Treatment

KALMAR, SWEDEN, November 25-27, 2003

Table 5. The average daily load of heavy metals in sewage sludge generated in the WWTPa, Wschod"

\begin{tabular}{|l|c|c|c|c|c|c|}
\hline \multirow{2}{*}{ Type of sludge } & Dry & $\mathrm{Zn}$ & $\mathrm{Cu}$ & $\mathrm{Pb}$ & $\mathrm{Cd}$ \\
\cline { 3 - 6 } & $\begin{array}{c}\text { matter } \\
\%\end{array}$ & \multicolumn{5}{|c|}{$\mathrm{kg} / \mathrm{d}$} \\
\hline Primary sludge & 3.5 & 10.1 & 2.3 & 0.20 & 0.04 \\
\hline Excess sludge & 0.6 & 11.9 & 2.6 & 0.09 & 0.04 \\
\hline Thcickened excess sludge & 5.8 & 11.0 & 2.6 & 0.05 & 0.04 \\
\hline Digested sludge & 3.2 & 20.9 & 4.7 & 0.24 & 0.09 \\
\hline Dewatered sludge & 22.0 & 24.0 & 4.5 & 0.10 & 0.04 \\
\hline
\end{tabular}

D.m. content generated sludge varied from $0.6 \%$ (excess sludge) to $22 \%$ (dewatered sludge). Zinc and copper represented 79.6 and $15.5 \%$, respectively, of the total content of analysed heavy metals. Lead and cadmium represented 3.7 and $1.1 \%$ of analysed elements, respectively. Analysis of heavy metals content in sludge indicated that mechanically dewatered sludge had the highest heavy metals content $(\mathrm{Zn}-780.4 \mathrm{mg} / \mathrm{kg}$ d.m., $\mathrm{Cu}-144.6 \mathrm{mg} / \mathrm{kg}$ d.m., $\mathrm{Pb}-5.4 \mathrm{mg} / \mathrm{kg}$ d.m. and Cda $2.3 \mathrm{mg} / \mathrm{kg} \mathrm{d.m.).}$

The crucial factor determining possible land application of sludge is heavy metals content. In Table 6 the average content of heavy metals in dewatered sludge is compared to the admissible values given in the Regulation issued by the Ministry of Environment on the $1^{\text {st }}$ August $2002[5]$.

Table 6. The content of heavy metals in dewatered sludge, mg/kg d.m.

\begin{tabular}{|l|c|c|}
\hline Heavy metals & $\begin{array}{c}\text { Mechanically dewatered } \\
\text { sludge }\end{array}$ & $\begin{array}{c}\text { Admissible contents of heavy metals in } \\
\text { digested sludge applied to land }\end{array}$ \\
\hline Zinc & 780.4 & 2500 \\
\hline Copper & 144.6 & 800 \\
\hline Lead & 5.4 & 500 \\
\hline Cadmium & 2.3 & 10 \\
\hline
\end{tabular}

Analysis of the values in Table 6 leads to the conclusion that concentrations of $\mathrm{Zn}, \mathrm{Cu}$, $\mathrm{Pb}$ and $\mathrm{Cd}$ do not limit land application of mechanically dewatered, digested sludge.

\section{DISCUSSION OF THE RESULTS}

Loads of heavy metals in sewage from subsequent stages of technological line and in reject waters from diffierent stages of sludge processing are presented in Fig. 3.

Important differences between inflowing and outflowing loads could be observed only in case of copper and zinc. Measurement method precision was not sufficient for evaluation 
KALMAR ECO-TECH'03

Bioremediation and Leachate Treatment

KALMAR, SWEDEN, November 25-27, 2003

of these differences for lead and cadmium. Maximal load of cadmium was $0.4 \mathrm{~kg} / \mathrm{d}$ and for lead it was $1.8 \mathrm{~kg} / \mathrm{d}$. The loads of $\mathrm{Zn}$ and $\mathrm{Cu}$ were far bigger. At the inflow the share of $\mathrm{Zn}$ and $\mathrm{Cu}$ in the total load of measured metals was 81.0 and $14.0 \%$, respectively, while the loads of $\mathrm{Pb}$ and $\mathrm{Cd}$ were only 3.9 and $1.1 \%$, respectively.

Analysis of the contents of heavy metals at subsequent sampling points indicated that the portion of cadmium and lead retained in the sludge was very small and these elements were almost in total discharged to the receiver with the effluent from the WWTP. However this statement needs to be confirmed by further investigations. High contents of zinc and copper were measured in sludge. Also high retention of zinc and copper in primary sludge was observed before modemization of former mechanical-chemical plant [7].

Thinking of natural environment protection (receiver's water quality), effectiveness of heavy metals removal is crucial. According to Bernacka and Pawlowska [1], during mechanical sewage treatment from 10 to $40 \%$ of the total load of metals can be removed, while biological treatment removes from 40 to $70 \%$ of heavy metals load. Effectiveness of $\mathrm{Zn}$ and $\mathrm{Cu}$ removal, calculated on the basis of the loads of these metals inflowing to and outflowing from mechanical and biological treatment units, was $34.4 \%$ and $80.7 \%$ for $\mathrm{Zn}$ and 44.4 and $80.0 \%$ for $\mathrm{Cu}$. Removal effiectiveness of each metal was calculated as a ratio of the difference of the metal load at the inflow and at the outflow to the load at the inflow.

Obtained results confirm that highly effective biological methods of sewage treatment lead to an increase of heavy metals accumulation in sewage sludge, especially in digested and dewatered sludge.

Mechanical dewatering of digested sludge frequently is a final step of sludge processing in Polish WWTPs. Hence sludge quality, especially heavy metals content, is a criterion of ultimate importance for its utilization. Analysed sludge met the criterion regarding heavy metals content, according to the Regulation of Environment Department of the $1^{\text {st }}$ August, 2002 [5].

\section{CONCLUSIONS}

1. The loads of zinc and copper $(27.7 \mathrm{~kg} / \mathrm{d}$ and $5.4 \mathrm{~kg} / \mathrm{d})$ were the biggest among analysed heavy metals.

2. Allocation of analysed heavy metals in the technological line of the WWTP differed depending on the type of metal. Only small extents of cadmium and lead were accumulated in the sludge, in contrast to zinc and copper. The loads of zinc and copper retained in the sludge were $780.4 \mathrm{mg} / \mathrm{kg}$ d.m. and $144.6 \mathrm{mg} / \mathrm{kg}$ d.m., respectively.

3. During mechanical swage treatment approximately $34.4 \%$ of $\mathrm{Zn}$ and $44.4 \%$ of $\mathrm{Cu}$ loads discharged to the WWTP were removed, while during biological treatment effiectiveness of metals removal increased to $80.7 \%$ for $\mathrm{Zn}$ and $80.0 \%$ for $\mathrm{Cu}$.

4. The contents of $\mathrm{Zn}, \mathrm{Cu}, \mathrm{Cd}$ and $\mathrm{Pb}$ in mechanically dewatered, digested sludge meet Polish obligatory criteria regarding heavy metals contents in sludge applied to land. 
[1] Bernacka J., Pwalowska L. Heavy metals in municipal sewage and possibilities of sewage sludge utilization. Proceedings of the Polish Conference "Operation of Wastewater Treatment Plants", Kielce 1995: 211-224. [in Polish]

[2] Hermanowicz W., Dozanska W., Dojlido J., Koziorowski B., Physical and chemical analyses methods of water and wastewater. Arkady. Warsaw 2000. [in Polish]

[3] Hobson P., Bousfield N., Sommers R. Anaerobic digestion of organic matter. Crit. Ren. Environm. Control 1974, 4: 131-191.

[4] Hooda P.S., Alloway B.J., Changes in operational fractions of trace metals in two soils during two-years of reaction time following sewage sludge treatment. Intern. J. Environ. Anal. Chem., 57, 1994, 289-311.

[5] Regulation of the Ministry of Environment of the $1^{\text {st }}$ August 2002. Dz.U.02/134/1a 40.

[6] Scancar J., Milcic R., Strazar M., Burica O., Total metal concentrations and partitioning of $\mathrm{cd}, \mathrm{Cr}, \mathrm{Cu}, \mathrm{Fe}, \mathrm{Ni}, \mathrm{Pb}$ and $\mathrm{Zn}$ in sewage sludge, The Science of the Total Environment 250, 2000: 9-10.

[7] Sommers L.E. Chemical composition of sewage sludges and analysis of their potential use as fertilizers. J. Environ. Quality 1976, 6: 225-232. 